\title{
CONTROLE JURISDICIONAL DE POLÍTICAS PÚBLICAS: a efetivação dos direitos sociais à luz da Constituição brasileira de 1988
}

THE JUDICIAL REVIEW OF PUBLIC POLICIES: the enforcement of social rights and the 1988 Constitution

\section{Elival da Silva Ramos ${ }^{1}$}

\begin{abstract}
Resumo:
O cerne do presente trabalho é a questão da implementação dos direitos fundamentais sociais, tema esse examinado sob perspectiva comparatística em seus delineamentos gerais, mas que toma como referência direta a Constituição brasileira em vigor, para se poder atribuir à análise um certo cunho operacional. Se os direitos sociais não compõem um conjunto uniforme de direitos, no tocante à eficácia, afirma-se que os direitos prestacionais, em sua maioria, são veiculados por normas programáticas, de eficácia limitada. Adverte-se para os males do ativismo judiciário exacerbado, ao se preconizar que a concretização desses direitos transite, necessariamente, pelo processo político, sem prejuízo do exercício da tutela jurisdicional em relação aos efeitos indiretos e mediatos que deles, desde logo, dimanam.
\end{abstract}

Palavras-chave: Direitos Fundamentais. Direitos prestacionais. Normas programáticas. Tutela jurisdicional. Constituição brasileira.

\begin{abstract}
:
This paper focuses primarily on the problem of the implementing of fundamental social rights. It takes the current Brazilian Constitution as a departing point but includes some comparative analyses as a framework to the main argument. It is argued that, although social rights do not form a uniform, cohesive set insofar their efficacy is concerned, the most citizens' rights to State relief is embodied in limited efficacy programmatic norms. The danger of excessive judicial activism is highlighted once the political process is presented as the proper means for the guaranteeing of such rights, notwithstanding the possibility of judicial review of concrete cases involving their effects.
\end{abstract}

Keywords: Constitution. Fundamental rights. Social rights. Efficacy. Public Policies. Judicial review.

Introdução

O tema da proteção jurisdicional dos direitos fundamentais de natureza econômica e social tem ocupado a agenda do constitucionalismo contemporâneo por apresentar múltiplas e instigantes imbricações com matérias de acentuada relevância, tais como: a atualização do princípio da separação dos Poderes; o controle jurisdicional sobre

1 Professor Associado de Direito Constitucional da Faculdade de Direito da Universidade de São Paulo. Procurador do Estado de São Paulo. Ex-Procurador Geral do Estado de São Paulo. 
a execução das políticas governamentais e seus limites; a crescente politização do Poder Judiciário; a eficácia das normas constitucionais; o princípio da máxima efetividade dos direitos fundamentais e suas implicações etc.

Por meio do presente trabalho, pretendo demonstrar que o regime jurídicoconstitucional dos direitos sociais de cunho prestacional, vale dizer, dos direitos sociais, cuja fruição plena esteja diretamente associada à execução de políticas públicas, goza de tipicidade em relação ao regime dos direitos de liberdade e mesmo em relação ao regime dos demais direitos econômicos e sociais.

De modo geral, não dispõem os direitos sociais a prestações estatais de plena proteção jurisdicional, o que não depõe, entretanto, em desfavor de sua fundamentalidade, nem anula o princípio da máxima efetividade (possível) dos direitos fundamentais. ${ }^{2}$ Importa notar, de outra parte, que o regime jurídico dos direitos sociais prestacionais é delineado por um determinado ordenamento constitucional, razão pela qual não deve causar espécie a constatação de que, vez por outra, tais direitos são configurados como direitos subjetivos de eficácia plena, amplamente reivindicáveis na esfera judicial.

O foco principal da análise, portanto, prende-se ao exame das condições observáveis, à luz do Direito Comparado, para a implementação dos direitos sociais cuja concretização esteja associada às políticas governamentais, não havendo a pretensão de se apresentar um completo estudo acerca da efetivação dos direitos fundamentais ou de todos aqueles direitos fundamentais compreendidos na categoria dos direitos sociais. Diante das relevantes especificidades que o Direito Constitucional Positivo de cada Estado apresenta em relação à matéria, adotou-se a proposta de detalhar a análise tendo como parâmetro o Direito Constitucional Positivo brasileiro. Isso permitirá trazer à baila algumas questões concretas que têm ocupado a doutrina constitucional de meu País, bem como a Administração Pública de nossos diversos níveis federativos ${ }^{3}$ e o Poder

\footnotetext{
O Professor da Faculdade de Direito de Coimbra, Gomes Canotilho, insere o princípio da máxima efetividade no seu catálogo de princípios tópicos da interpretação constitucional, observando que "é um princípio operativo em relação a todas e quaisquer normas constitucionais, e embora a sua origem esteja ligada à tese da actualidade das normas programáticas" "é hoje sobretudo invocado no âmbito dos direitos fundamentais (no caso de dúvidas deve preferir-se a interpretação que reconheça maior eficácia aos direitos fundamentais)": CANOTILHO, J. J. Gomes. Direito constitucional e teoria da constituição. 7. ed. Coimbra: Almedina, 2003 p. 1.224. Todavia, como bem adverte Celso Ribeiro Bastos, o princípio "significa que, sempre que possível, deverá ser o dispositivo constitucional interpretado num sentido que lhe atribua maior eficácia": BASTOS, Celso Ribeiro. Hermenêutica e interpretação constitucional. 2. ed. São Paulo: Celso Bastos - Instituto Brasileiro de Direito Constitucional, 1999. p. 104.

3 O Brasil é uma República Federativa estruturada em três níveis de competência territorial, que correspondem à esfera de atuação das pessoas políticas (com capacidade legislativa) que integram a federação brasileira: União (nível central), Distrito Federal e Estados (nível regional) e Municípios (nível local). Vejam-se os arts. $1^{\circ}$, caput e 18, caput, da Constituição, de 5 de outubro de 1988.
} 
Judiciário, enquanto instância de controle jurídico dos demais Poderes. A propósito, as repercussões crescentes que as decisões judiciais têm provocado no planejamento e ações governamentais apontam para a relevância e complexidade do tema, a merecer as luzes da comunidade internacional de constitucionalistas.

1. Os direitos sociais vinculados à implementação de políticas públicas

\subsection{Os direitos sociais enquanto direitos fundamentais da pessoa humana}

Se o Estado democrático importa na concepção de Estado em que o Ser Humano ocupa uma posição central, ${ }^{4}$ é seu corolário lógico a existência de direitos das pessoas em face do Estado, de modo a que a existência deste se justifique em função da plena realização daquelas. ${ }^{5}$ Bem por isso, o surgimento das primeiras Constituições documentais e rígidas assinalou a positivação de direitos, então denominados de direitos do homem, a quem o Estado deveria prestar reverência, ${ }^{6}$ e que já se encontravam presentes no modelo dogmático do jusnaturalismo.

Como bem expressa Jorge Miranda, "a locução direitos fundamentais tem sido nas últimas décadas a preferida pela doutrina e pelos textos constitucionais para designar os direitos das pessoas frente ao Estado que são objeto da Constituição". ${ }^{7}$ Entretanto, o catálogo de direitos fundamentais constitucionalmente consagrado não ostenta um conteúdo uniforme ao longo de mais de dois séculos de vigência do Estado de Direito democrático, comportando a introdução de novos direitos e a reformulação de direitos já anteriormente acolhidos, na medida em que os desafios que se antepõem à plena realização do ser humano vão se modificando, à luz do contexto histórico.

4 Razão pela qual o princípio da dignidade da pessoa humana é considerado princípio fundamental nos sistemas constitucionais contemporâneos de índole democrática. A título de ilustração, vejam-se a Constituição espanhola, de 1978 (art. 10.1) e a brasileira, de 1988 (art. $1^{\circ}$, III).

5 Destarte, no Estado democrático o povo (conjunto das pessoas vinculadas ao Estado por relação de nacionalidade) detém a titularidade da soberania e, em conseqüência, participa, direta ou indiretamente, do exercício do poder, que deve ter em mira a plena satisfação das necessidades das pessoas, sob a garantia dos princípios delineadores do Estado de Direito.

${ }^{6}$ As primeiras Constituições documentais e rígidas, trazidas pelas revoluções liberais do século XVIII, se colocavam a serviço da democracia, de tal sorte que não haveria uma autêntica Constituição se nela não estivesse assegurada a garantia dos direitos e nem tampouco determinada a separação dos Poderes (art. 16 da Declaração dos Direitos do Homem e do Cidadão, de 26-8-1789).

7 MIRANDA, Jorge. Manual de direito constitucional. 2. ed. Coimbra: Coimbra Editora, 1993. t. 4, p. 48. 
Adespeito de certa oposição doutrinária, ${ }^{8}$ os estudos de Direito Constitucional Comparado revelam razoável consenso na utilização da expressão "gerações de direitos fundamentais" para indicar o fenômeno do adensamento do catálogo desses direitos, com a incorporação de novas posições jurídicas ativas, dotadas de estrutura e funções assemelhadas e que, por conseguinte, podem ser agrupadas em uma mesma categoria. ${ }^{9}$ Assim é que as Cartas oitocentistas ocupavam-se, essencialmente, das liberdades públicas e dos direitos políticos, situados como instrumentos de contenção do arbítrio estatal, em prol da liberdade individual. ${ }^{10}$ A partir do advento das Constituições social-democráticas, capitaneadas pela Constituição alemã de Weimar, de 1919, uma nova categoria de direitos fundamentais ${ }^{11}$ obteve reconhecimento normativo e doutrinário, a dos direitos econômicos e sociais, fenômeno esse que constitui o marco de uma profunda reformulação no papel do Estado democrático, do qual se passa a exigir que proporcione as condições materiais necessárias ao pleno desenvolvimento da personalidade humana. ${ }^{12}$

No último quarto do século passado, passou-se a falar em uma terceira geração de direitos fundamentais, muito mais heterogênea e, portanto, refratária à compreensão em uma única categoria do que as duas primeiras. ${ }^{13}$ Trata-se dos chamados direitos de solidariedade, voltados à preservação da espécie humana diante das mais recentes ameaças

\footnotetext{
8 É o caso do posicionamento de TRINDADE, Antônio Augusto Cançado. El derecho internacional de los derechos humanos en el siglo XXI. Santiago: Editorial Jurídica de Chile, 2001. p. 132, apud ALCALÁ, Humberto Nogueira. A dignidade da pessoa e os direitos econômicos, sociais e culturais: uma aproximação latino-americana. Revista de Direito Constitucional e Internacional, São Paulo, p. 27, jul./set. 2005, em que aduz: "Cançado Trindade considera inadequado e fragmentário falar de geração de direitos, considerando mais adequado referir-se a uma expansão, acumulação e fortalecimento dos direitos humanos com uma visão integrada de todos os direitos humanos". Não assiste razão, todavia, ao ilustre Juiz da Corte Interamericana de Direitos Humanos, porquanto a idéia de "gerações de direitos" não implica, necessariamente, na exclusão das categorias mais longevas, que podem conviver com aquelas mais recentes, do mesmo modo que as pessoas de uma geração convivem com ascendentes e descendentes.

9 Dentre inúmeros comparatistas, menciono GARRIDO, Diego López; GARROTE, Marcos; PEGORARO, Lucio. (Coords.). Nuevo derecho constitucional comparado. Valência: Tirant lo Blanche, 2000. p. 162 e ss, que discorre sobre quatro gerações de direitos humanos: direitos de liberdade, direitos econômicos e sociais, direitos de solidariedade e direitos da sociedade tecnológica.

${ }^{10}$ O próprio exercício dos direitos políticos, mais do que manifestação do princípio da soberania popular (já que admitia restrições de natureza sócio-econômica), consubstanciava autêntica garantia da liberdade individual, servindo para frear potenciais abusos do poder estatal.

${ }^{11}$ Aliás, segundo MIRANDA, Jorge. op. cit., t. 4, p. 49, a Constituição de Weimar contribuiu decisivamente para a generalização no uso da expressão "direitos fundamentais".

${ }^{12} \mathrm{Na}$ expressão de Angelo Rinella, "com base nas normas constitucionais, o Estado assume a função de intervir ativamente no sistema econômico-social de modo a proporcionar, em relação aos direitos de liberdade, condições de igualdade substancial": Diritto Costituzionale e Pubblico (GARRIDO, Diego López; GARROTE, Marcos; PEGORARO, Lucio. (Coords.).op. cit., p. 182.)

${ }_{13}$ Alguns Autores ponderam que não se está diante de uma nova categoria de direitos fundamentais, e sim de uma nova dimensão desses direitos: Id. Ibid., p. 166.
} 
à sua perpetuação, as quais somente podem ser enfrentadas adequadamente mediante a cooperação internacional. ${ }^{14}$ Cogita-se nessa transição entre os séculos XX e XXI de uma quarta vaga de direitos fundamentais, que estaria voltada ao enfrentamento de questões trazidas pelo uso intensivo da informática, inclusive no ambiente da rede mundial de computadores, e da biotecnologia.

$\mathrm{Na}$ presente análise, irei me ater aos direitos fundamentais de segunda geração, usualmente aglutinados sob o título abrangente de direitos econômicos e sociais mas, que, como se sabe, abarcam diversas modalidades de direitos, conformados de maneira bem distinta pelo Legislador Constituinte, embora em todos eles esteja presente o intuito de assegurar a todas as pessoas as condições materiais indispensáveis à fruição da liberdade e ao desenvolvimento de sua personalidade.

\subsection{As diversas modalidades de direitos sociais}

A inclusão de direitos associados à melhoria das condições de vida da classe trabalhadora é considerada um dos marcos do advento do constitucionalismo social-democrático. Entretanto, do exame concreto de Constituições com esse perfil, resulta a conclusão inelutável de que não há uniformidade de tratamento em relação a essa categoria de direitos fundamentais nem mesmo no âmbito de um determinado ordenamento constitucional. Daí as inúmeras sistematizações doutrinárias que, calcadas no Direito Positivo de um Estado em particular, aludem a diversas modalidades de direitos sociais.

No Direito Constitucional brasileiro, José Afonso da Silva propôs uma classificação que tem em vista o objeto diferenciado desses direitos, sob o regime da Carta de 1988, fazendo distinção entre " a) direitos sociais relativos ao trabalhador; b) direitos sociais relativos à seguridade, compreendendo os direitos à saúde, à previdência e à assistência social; c) direitos sociais relativos à educação e à cultura; d) direitos sociais relativos à família, criança, adolescente e idoso; e) direitos sociais relativos ao meio ambiente". ${ }^{15}$ Entendo que classificações fundadas no critério do objeto do direito social

\footnotetext{
14 São mencionados como integrantes da terceira geração de direitos fundamentais o direito à paz, o direito ao desenvolvimento, o direito ao patrimônio comum da humanidade, o direito à comunicação, o direito à autodeterminação dos povos e o direito ao meio ambiente: veja-se FERREIRA FILHO, Manoel Gonçalves. Direitos humanos fundamentais. 7. ed. São Paulo: Saraiva, 2005. p. 57-69.

15 SILVA, José Afonso da. Garantias econômicas, políticas e jurídicas da eficácia dos direitos sociais. Revista da Academia Brasileira de Direito Constitucional, Curitiba, v. 3, p. 305, 2003. Observe-se que o conhecido constitucionalista brasileiro arrola dentre os direitos sociais o direito ao meio ambiente sadio e equilibrado, mais freqüentemente situado no rol dos direitos de solidariedade.
} 
não apresentam significativa relevância, porquanto, nesse caso, direitos com regimes jurídicos bastante diferenciados podem aparecer lado a lado, enquanto direitos modelados de modo similar pelo Constituinte acabam se distanciando.

Bem mais frutífero foi o caminho trilhado por Gomes Canotilho, que parte da constatação de que os direitos fundamentais desempenham funções distintas, sendo particularmente úteis à reflexão ora desenvolvida as funções de defesa e de prestação social. ${ }^{16}$ Assim, os direitos fundamentais cumpririam função de defesa quando ao mesmo tempo em que asseguram uma esfera de autonomia individual (liberdade positiva), impedem o Poder Público de interferir na movimentação que ocorre no seu âmago (liberdade negativa). Por seu turno, os direitos sociais a prestações, em sentido estrito, importariam no "direito do particular a obter algo através do Estado (saúde, educação, segurança social)", embora se ressalve que "se o particular tiver meios financeiros suficientes $e$ houver resposta satisfatória do mercado à procura destes bens sociais, ele pode obter a satisfação das suas 'pretensões prestacionais'através do comércio privado (cuidados de saúde privados, seguros privados, ensino privado)" ${ }^{17}$

Ora, levando em conta as funções desempenhadas pelos direitos fundamentais, pode-se identificar ao menos três modalidades distintas de direitos econômicos e sociais: os direitos relacionados à organização sindical dos trabalhadores e ao exercício de reivindicações de natureza laboral, tais como as liberdades de associação sindical e o direito de greve; os direitos que a Constituição reconhece aos trabalhadores, uma vez caracterizada a relação de emprego; os direitos sociais prestacionais em sentido estrito, cuja implementação exige intensa atividade estatal, a partir da formulação de políticas públicas afeiçoadas à teleologia constitucional. ${ }^{18}$

No primeiro caso, se está claramente diante de liberdades públicas ou de direitos de defesa, muito embora também constituam instrumentos que asseguram aos trabalhadores maior efetividade no exercício de suas reivindicações por melhores salários

${ }^{16}$ CANOTILHO, J.J. GOMES. Direito constitucional e teoria da constituição. cit., p. 407-10. Além das funções de defesa e de prestação social, aponta o constitucionalista luso as funções de proteção perante terceiros e de não-discriminação.

17 Id. Ibid., p. 408.

18 Idêntica percepção quanto às modalidades de direitos sociais expressou Ingo Wolfgang Sarlet, em obra de grande valia, (SARLET, Ingo Wolfang. A eficácia dos direitos fundamentais. 2. ed. Porto Alegre: Livraria do Advogado, 2001. p. 52) "Ainda na esfera dos direitos da segunda dimensão, há que atentar para a circunstância de que estes não englobam apenas direitos de cunho positivo, mas também as assim denominadas 'liberdades sociais', do que dão conta os exemplos da liberdade de sindicalização, do direito de greve, bem como do reconhecimento de direitos fundamentais aos trabalhadores, tais como o direito a férias e ao repouso semanal remunerado, a garantia de um salário mínimo, a limitação da jornada de trabalho, apenas para citar alguns dos mais representativos". 
e condições de trabalho. No tocante aos direitos atinentes ao contrato de trabalho, constatase que dependem, em boa dose, de atuação estatal que propicie as condições econômicas favoráveis ao pleno emprego. Em outras palavras, há um direito social prestacional, o direito de acesso ao trabalho, que lhes serve de pressuposto. Todavia, uma vez no âmbito do contrato de trabalho, seja ele coletivo ou individual, tais direitos demandam do Estado apenas a proteção jurisdicional, enquanto garantia geral dos direitos fundamentais. Finalmente, os direitos às amplas prestações estatais, decorrentes da execução de políticas públicas, constituem categoria à parte, sendo usualmente veiculados por normas constitucionais de baixa densidade significativa e que exigem, pois, a intervenção do legislador infraconstitucional para lhes completar a modelagem.

\subsection{A eficácia das normas constitucionais veiculadoras de direitos sociais}

\subsubsection{As normas constitucionais e sua eficácia}

É de todos conhecida a clássica distinção que o Direito Constitucional estadunidense legou ao constitucionalismo entre normas executáveis por si mesmas e normas não-executáveis por si mesmas (self-executing provisions e not self-executing provisions). Ao dissertar acerca das normas não-exeqüíveis por si mesmas, em passagem da qual se pode extrair o conceito antagônico, Jorge Miranda anotou que "nelas se verifica - por motivos diversos de organização social, política e jurídica - um desdobramento: por um lado, um comando que substancialmente fixa certo objetivo, atribui certo direito, prevê certo órgão; e, por outro lado, um segundo comando, implícito ou não, que exige do Estado a realização desse objetivo, a efetivação desse direito, a constituição desse órgão, mas que fica dependente de normas que disponham as vias ou os instrumentos adequados a tal efeito". 19

Em monografia largamente difundida no Brasil, José Afonso da Silva, inspirado nas lições de Vezio Crisafulli, ${ }^{20}$ formulou uma classificação alternativa à tradicional, a qual, para ele, transmitia a idéia de ineficácia total das not self-executing provisions. ${ }^{21}$ Procurou o Autor brasileiro fugir do modelo dicotômico, ao sustentar que

\footnotetext{
19 MIRANDA, Jorge. Manual de direito constitucional. 3. ed. Coimbra: Coimbra Editora, 1996. t. 2, p. 247.

${ }^{20}$ CRISAFULLI, Vezio. La Costituzione e le sue disposizioni di principio. Milão: Giuffrè, 1953.

${ }^{21}$ SILVA, José Afonso da. Aplicabilidade das normas constitucionais. 6. ed. São Paulo: Malheiros, 2003. p. 75: "A classificação pura e simples das normas constitucionais em auto-aplicáveis e não auto-aplicáveis não corresponde, com efeito, à realidade das coisas e às exigências da ciência jurídica, nem às necessidades práticas de aplicação das constituições, pois sugere a existência, nestas, de normas ineficazes e destituídas de
} 
as normas constitucionais quanto à eficácia se distribuíam em três categorias: normas constitucionais de eficácia plena; normas constitucionais de eficácia contida; e normas constitucionais de eficácia limitada. Nos dois primeiros grupos, estariam situadas as normas dotadas pelo Constituinte de elementos suficientes para incidir "direta $e$ imediatamente sobre a matéria que lhes constitui objeto", com a diferença, no tocante à segunda categoria, que poderiam estas vir a ter a sua eficácia restringida por legislação superveniente, explícita ou implicitamente autorizada pelo texto constitucional. Por seu turno, as normas de eficácia limitada seriam aquelas que careceriam de plenas condições técnico-jurídicas para a direta e imediata regulação da matéria que pretendem disciplinar, o que não significa que não produzam alguns efeitos, ainda que de índole indireta e mediata. $^{22}$

Importante contribuição ao tema adveio do constitucionalista português Jorge Miranda, ao combinar a classificação tradicional, proveniente da doutrina estadunidense, com outra, fundada em critério algo diverso, que aparta as normas constitucionais em preceptivas e programáticas, tendo em vista já aqui não a completude ou incompletude da norma em si, mas sim a aptidão do legislador, constitucional ou infraconstitucional, para ordenar autonomamente os fatos objetos de regulação (normas preceptivas) ou a sua incapacidade para tanto, ficando a plena obtenção dos fins almejados dependente de um conjunto de atividades estatais de natureza não-normativa e da existência de condições econômico-sociais favoráveis (normas programáticas). ${ }^{23}$ Bem por isso, pode-se afirmar que todas as normas exeqüíveis por si mesmas são preceptivas, ao passo que dentre as normas não-exeqüíveis por si mesmas algumas são preceptivas e outras programáticas. ${ }^{24}$

De minha parte, considero as normas constitucionais, quanto à eficácia, subdividas em duas grandes categorias: as normas de eficácia plena e as de eficácia limitada, sendo que, dentre as de eficácia plenas, algumas, não muito numerosas, pertencem ao subgrupo das normas de eficácia plena, porém restringível. ${ }^{25} \mathrm{O}$ que importa, todavia, sob o ângulo das questões jurídicas complexas trazidas pela implementação dos direitos econômicos e sociais é considerar que se as normas constitucionais dotadas de plenitude

imperatividade, como bem demonstra o conceito de Cooley, quando fala em regras 'sem estabelecer normas por cujo meio se logre dar a esses princípios vigor de lei"”.

${ }^{22}$ Veja-se SILVA, José Afonso da. Aplicabilidade das normas constitucionais. 6. ed. São Paulo: Malheiros, 2003. p. 81-3.

${ }^{23}$ MIRANDA, Jorge. op. cit., t. 2, p. 246-7.

${ }^{24}$ Id. Ibid., p. 248.

${ }^{25}$ Há correspondência com as normas de eficácia contida de que nos fala José Afonso da Silva, que, data venia, não usou da melhor terminologia, porquanto a contenção da eficácia dessas normas, produzida por legislação superveniente, existe apenas potencialmente na norma em si. 
eficacial são todas elas preceptivas, no tocante às normas de eficácia limitada algumas são, igualmente, preceptivas, demandando apenas complementação legislativa, ao passo que outras são de índole programática, exigindo bem mais do que a mera edição de normas infraconstitucionais para gozar de aplicabilidade integral. Em outras palavras, a questão de sua implementação não pode ser equacionada com plena autonomia pelo direito e seu instrumental, envolvendo, a par da concretização legislativa, o exercício da função de governo (escolha de políticas públicas), da função administrativa, quer no tocante à prática de atos administrativos, quer no tocante à atividade material da Administração, a alocação e dispêndio de recursos financeiros, todas essas ações pressupondo a existência de condições sócio-econômicas favoráveis ao seu desenrolar. ${ }^{26}$

\subsubsection{Direitos sociais dotados de plena proteção jurisdicional}

Já vimos anteriormente que os direitos sociais não constituem uma categoria uniforme de direitos fundamentais, comportando algumas modalidades, submetidas a regime jurídico-constitucional diferenciado, em razão da estrutura e função da norma que os abriga. Ora, tal diferenciação de regime se dá, sobretudo, na configuração de níveis mais ou menos intensos de eficácia jurídica.

Nesse sentido, impõe-se o reconhecimento da existência de direitos sociais aos quais se assegura ampla tutela jurisdicional, na medida em que veiculados por normas constitucionais de eficácia plena e de natureza preceptiva. É o caso, por exemplo, da chamada liberdade sindical, em suas várias dimensões, ${ }^{27}$ usualmente agasalhada em normas compostas por elementos suficientes para propiciar o imediato e direto exercício da franquia, que desempenha, de outra parte, uma função eminentemente defensiva. ${ }^{28}$

\footnotetext{
${ }^{26}$ Ainda uma vez, vem bem a propósito a lição de Jorge Miranda: "Nas normas exeqüiveis por si mesmas, os comandos constitucionais atualizam-se só por si; nas normas exeqüiveis preceptivas, aos comandos constitucionais acrescem as normas legislativas; e nas normas não exeqüiveis por si mesmas programáticas tem ainda de se dar uma terceira instância - a instância política, administrativa e material, única com virtualidade de modificar as situações e os circunstancialismos econômicos, sociais e culturais subjacentes à Constituição". (MIRANDA, Jorge. Manual de direito constitucional. 3. ed. Coimbra: Coimbra Editora, 1996. t. 2, p. 248-9).

${ }^{27}$ Com efeito, compreende a referida liberdade pública o direito de criar organização sindical, a liberdade de exercício de atividades sindicais, o direito à autodeterminação dos sindicatos e a liberdade de filiação sindical. Sobre o assunto, vejam-se CESARINO JÚNIOR, A. F. Direito social brasileiro. 6. ed. São Paulo: Saraiva, 1970. v. 1, p. 124-36, e MORAES, Alexandre de. Direito constitucional. 21 ed. São Paulo: Atlas, 2007. p. 1867. Essas várias dimensões da liberdade sindical foram expressamente arroladas pelo art. 55, n. 2, alíneas de $a$ a $d$, da Constituição portuguesa, acrescentando, ainda, o direito de tendência, "nas formas que os respectivos estatutos determinarem" (alínea $e$ ).

${ }^{28} \mathrm{Na}$ Constituição de Portugal, a liberdade sindical foi situada no Título II, concernente aos "Direitos, liberdades e garantias", submetendo-se, pois, ao regime jurídico que lhes é próprio, traçado pelos arts. 18 e 19 daquela
} 
No abrangente rol de direitos conferidos pela Constituição brasileira, de 1988, aos trabalhadores urbanos e rurais em seu art. $7^{\circ}$, boa parte deles, de igual modo, assenta-se em normas preceptivas de eficácia plena, o que lhes assegura completa proteção perante a esfera judiciária competente. ${ }^{29}$ Esses direitos, vale observar, são exigíveis perante os empregadores urbanos e rurais, no âmbito de relações contratuais de trabalho, cujo florescimento, é certo, deve ser favorecido pelo Estado mediante políticas de pleno emprego. ${ }^{30}$

1.3.3. Direitos sociais sediados em normas constitucionais preceptivas de eficácia limitada

Por vezes, o Constituinte contempla direitos econômicos e sociais cuja fruição pelos respectivos beneficiários fica condicionada apenas à complementação dos elementos integrantes da norma que os abriga, tarefa essa eminentemente legislativa. A partir do advento da legislação integradora, bastará a ocorrência do fato descrito na hipótese normativa para que o direito possa ser plenamente gozado, não havendo a necessidade de atuação estatal direta para que a conformação da realidade fática dê ensejo à efetiva aquisição do direito.

Em outros termos, cuida-se aqui de normas constitucionais de natureza preceptiva, mas de eficácia limitada, que, por razões de política legislativa, não foram configuradas de maneira a permitir o imediato manejo dos direitos que veicula, atribuindose ao legislador infraconstitucional, e exclusivamente a ele, a tarefa de dotar o mandamento superior de plenitude eficacial.

Exemplo dessa categoria de direitos sociais pode ser encontrado no inciso XI, do art. $7^{\circ}$, da Constituição brasileira, de 1988, que defere aos trabalhadores a "participação nos lucros, ou resultados, desvinculada da remuneração, e, excepcionalmente, participação

Carta constitucional, com a previsão expressa da aplicabilidade imediata dos sobreditos direitos e garantias fundamentais (art. 18, n. 1).

${ }^{29}$ É o caso, por exemplo, dos direitos consignados nos incs. VIII, XIII, XV, XVI, XVII e XVIII do mencionado art. $7^{\circ}$. Em sentido diverso, a Constituição portuguesa sujeitou os direitos dos trabalhadores ao regime dos "Direitos e deveres econômicos, sociais e culturais" (Título III), bem mais acanhado do que o regime das liberdades públicas no plano da proteção jurisdicional.

${ }^{30}$ Apenas no tocante ao direito ao trabalho, que cria as condições para a efetiva fruição dos direitos dos trabalhadores, pode-se falar em direito social de índole prestacional. Por outro lado, mesmo que o Estado atue como empregador, ficando obrigado, pois, a proporcionar aos servidores públicos alguns dos direitos dos trabalhadores (art. 39, $\S 3^{\circ}$, da Constituição brasileira), não se trata, propriamente, de direitos sociais de prestação, ao menos em sentido estrito, associados à implementação de políticas públicas de vasto alcance. 
na gestão da empresa, conforme definido em lei". ${ }^{31}$ Submete-se a regime jurídico similar o direito dos trabalhadores a participar na gestão das empresas previsto no art. 57 da Constituição da Colômbia, de 1991.32

\subsubsection{Direitos sociais veiculados por normas programáticas: proteção jurisdicional indireta e direta}

A face mais visível dos direitos econômicos e sociais é aquela que os revela associados a normas constitucionais de eficácia limitada e de natureza programática, normas essas que fixam diretrizes à atuação do Poder Público, o qual tem o dever jurídico de implementá-las mediante o planejamento de políticas públicas adequadas, cuja execução envolve desde a edição de normas legais e regulamentares até a prestação material de serviços públicos, o que demanda a alocação e dispêndio de recursos financeiros. ${ }^{33}$ Os direitos sociais a prestações estatais, em sentido estrito, estão quase todos conformados dessa maneira, o que remete a sua aquisição e plena exigibilidade ao momento em que os serviços públicos correlatos estiverem organizados e em funcionamento, estando normativamente definidos os procedimentos e condições para a sua fruição. Trata-se, pois, sob esse ângulo e situada a análise no plano normativo, de direitos potenciais ou in fieri.

Não significa isto que os direitos sociais programáticos fiquem totalmente a descoberto da proteção jurisdicional. O que não se admite é a intervenção do Poder Judiciário diretamente voltada à sua tutela, porquanto as normas que os veiculam não contêm os elementos que lhes tracem uma completa modelagem, a ser concluída pela disciplina de nível infraconstitucional. Não é suficiente para a sua caracterização, ademais, a simples interposição normativa, a qual deve ser conjugada à estruturação material da atividade estatal que os propicia. Importa salientar, por fim, que a missão desses direitos

${ }_{31}$ A Lei Federal n. 10.101, de 19-12-2000, veio completar a eficácia da norma constitucional que consagra o direito à participação dos empregados nos lucros ou resultados das empresas.

${ }^{32}$ Estabelece o citado dispositivo constitucional: "A lei poderá estabelecer os estímulos e os meios para que os trabalhadores participem da gestão das empresas".

${ }^{33}$ Gomes Canotilho faz referência a 4 (quatro) modelos de positivação dos direitos econômicos e sociais, de acordo com a estrutura e finalidade das normas que os veiculam: (I) normas programáticas; (II) normas de organização; (III) normas que atuam como garantias institucionais; (IV) normas que asseguram autênticos direitos públicos subjetivos. Essas últimas consubstanciam normas constitucionais de eficácia plena, ao passo que os dois modelos intermediários estão assentados em normas de eficácia limitada de natureza preceptiva. Porém, pode-se vislumbrar a predominância do primeiro modelo, que utiliza normas constitucionais de eficácia limitada de natureza programática, na positivação dos direitos sociais, quando se menciona que "as normas consagradoras de direitos sociais, econômicos e culturais são, segundo alguns autores, normas programáticas”: CANOTILHO, J.J. Gomes. Direito Constitucional e Teoria da Constituição. cit., p. 474-6. 
está compreendida naquilo que Jorge Miranda denominou de dimensão prospectiva da Constituição, ${ }^{34}$ o que reduz a sua eficácia regulatória em tempo presente.

Se, por um lado, os direitos sociais sediados em normas programáticas carecem de tutela jurisdicional direta, não lhes falta, por outro, a proteção indireta, a partir do momento em que se firmou o reconhecimento de sua força vinculativa. Bem por isso, atribui-se a essas normas eficácia limitada, o que importa em alguma eficácia, ainda que insuficiente para a plena realização das prescrições que encerram.

O constitucionalista brasileiro, Ingo Wolfgang Sarlet, apresenta um elenco bastante completo acerca das formas pelas quais se manifesta a eficácia indireta dos direitos sociais de índole programática, compreendendo: a) o efeito revocatório em relação às normas contrárias precedentemente editadas; b) a vinculação do legislador ordinário e do poder regulamentar ao programa constitucionalmente estabelecido, de sorte que os atos normativos editados em descompasso com os seus parâmetros sujeitam-se à sanção de inconstitucionalidade; c) a utilização desses direitos como verdadeiros princípios constitucionais orientadores da atividade de interpretação, integração e aplicação das demais normas constitucionais e infraconstitucionais; d) a proibição de retrocesso no tocante aos direitos que já receberam a necessária concretização normativo-institucional, ressalvada, acrescento eu, a ocorrência de relevante alteração nas condições fáticas que cercaram a implementação do direito. ${ }^{35}$ Se os direitos sociais inseridos em normas de eficácia limitada programáticas não caracterizam, senão potencialmente, autênticos direitos públicos subjetivos a prestações estatais, não deixam de representar desde logo, por força de sua mera inserção constitucional, situações jurídicas ativas ou de vantagem, na medida em que é vedado ao Poder Público, no desempenho de toda e qualquer função estatal, atuar de modo contrário aos parâmetros eles definidos pelas prescrições constitucionais, naquilo que a doutrina denomina de dimensão negativa dos direitos sociais a prestações. $^{36}$

\footnotetext{
${ }^{34}$ MIRANDA, Jorge. Manual de direito constitucional. 3.ed. Coimbra: Coimbra Editora, 1996. t. 2, p. 245.

35 SARLET, Ingo Wolfang. A eficácia dos direitos fundamentais. 2. ed. Porto Alegre: Livraria do Advogado, 2001. p. 271-6. De teor assemelhado são as ponderações de Jorge Miranda sobre o tema: Manual, cit., t. 2, p. 250-2.

36 Sobre essa temática, veja-se Id. Ibid., p. 274: "Os direitos fundamentais a prestações - mesmo os que reclamam uma interpositio legislatoris - geram sempre algum tipo de posição jurídico-subjetiva, tomando-se esta, consoante assinalado alhures, em um sentido amplo, e não restrita à concepção de um direito subjetivo individual a determinada prestação estatal, possibilidade esta que continua suscitando acirrada controvérsia (...)".
} 
2. A proteção dos direitos sociais a prestações na Constituição brasileira, de 1988

2.1. Inexistência de completa proteção jurisdicional

A Constituição do Brasil, de 5 de outubro de 1988, inspirada pelo disposto no art. 18, n. 1, da Constituição portuguesa, de $1976,{ }^{37}$ estabeleceu, em seu art. $5^{\circ}, \S 1^{\circ}$, que "as normas definidoras dos direitos e garantias fundamentais têm aplicação imediata". Não pairam dúvidas sobre a intenção do Constituinte brasileiro de atribuir às normasmatrizes dos direitos fundamentais ${ }^{38}$ um estatuto diferenciado no tocante à eficácia, de modo a evitar a dissociação entre o texto constitucional e a sua implementação. Entretanto, sem que se deva proclamar a inutilidade do dispositivo, é preciso reconhecer que não há correspondência plena entre a sua dicção textual e as conseqüências que dele efetivamente dimanam. Em outras palavras, não se pode extrair do $\S 1^{\circ}$, do art. $5^{\circ}$, da Constituição brasileira a conseqüência de haver eliminado a existência de normas-sede de direitos fundamentais de eficácia limitada, contrariando a técnica utilizada pelo próprio Constituinte na estruturação de alguns desses direitos e, sobretudo, a finalidade de muitos deles, que é a de servir de norte para os Poderes Públicos, em uma contínua e prospectiva atividade de concretização da vontade constitucional. ${ }^{39}$

Uma primeira decorrência da norma-princípio da aplicabilidade imediata é a de que as normas consagradoras de direitos fundamentais devem ser presumidas pelo aplicador como de eficácia plena, "de tal sorte que eventual recusa de sua aplicação, em virtude da ausência de ato concretizador, deverá ser necessariamente fundamentada" ${ }^{40}$ Se a toda e qualquer norma constitucional se aplica o postulado hermenêutico da máxima

${ }^{37} \mathrm{O}$ referido preceito da Constituição de Portugal diz respeito ao regime jurídico reforçado dos direitos de defesa (direitos, liberdades e garantias) e está assim redigido: "Os preceitos constitucionais respeitantes aos direitos, liberdades e garantias são diretamente aplicáveis e vinculam as entidades públicas e privadas." Poder-se-ia, de outra parte, buscar no art. 1, III, da Lei Fundamental de Bonn a fonte inspiradora do $\S 1^{\circ}$, do art. 5º da Constituição brasileira, de 1988. Todavia, não apenas o padrão lingüístico conspira contra essa hipótese, como também a redação do dispositivo constitucional germânico, cujo significado tem se prestado a polêmicas intensas na própria Alemanha: veja-se, a propósito, SARLET, Ingo Wolfang. A eficácia dos direitos fundamentais. 2. ed. Porto Alegre: Livraria do Advogado, 2001. p. 239, nota 63.

38 A despeito da inserção da norma da aplicabilidade imediata no Capítulo I, do Título II, da Constituição, que trata dos direitos e deveres individuais e coletivos (correspondentes, grosso modo, às liberdades públicas e suas garantias), firmou-se o consenso doutrinário no sentido de que a disposição se aplica, em princípio, a todas as categorias de direitos fundamentais.

39 Nessa linha de equilíbrio, situa-se o pensamento de SARLET, Ingo Wolfang. op. cit., p. 243-9.

${ }^{40}$ Id. Ibid., p. 250. Para o citado autor, "a presunção da aplicabilidade imediata e plena eficácia que milita em favor dos direitos fundamentais constitui, em verdade, um dos esteios de sua fundamentalidade formal no âmbito da Constituição". 
efetividade, ${ }^{41}$ no que concerne às normas veiculadoras de direitos e garantias fundamentais esse princípio-instrumental se vê reforçado pela presunção que milita em favor de sua eficácia plena.

Jorge Miranda, referindo-se ao art. 18, n. 1, da Constituição de Portugal, extrai da norma da aplicabilidade imediata as seguintes conseqüências: "a) salientar $o$ caráter preceptivo, e não programático, das normas sobre direitos, liberdades e garantias; b) afirmar que estes direitos se fundam na Constituição, e não na lei; c) sublinhar (na expressão bem conhecida da doutrina alemã) que não são os direitos fundamentais que se movem no âmbito da lei, mas a lei que deve mover-se no âmbito dos direitos fundamentais". ${ }^{42}$ Entretanto, reconhece o constitucionalista luso que mesmo o regime de eficácia reforçada das liberdades públicas não impede, por completo, a existência de normas sobre direitos, liberdades e garantias que ostentam natureza preceptiva, porém não gozam de eficácia plena, por dependerem da interpositio legislatoris ${ }^{43}$. A eficácia limitada de que são dotados esses preceitos normativos importa em aplicabilidade indireta ou mediata, nos termos em que a questão foi posta no item 1.3.4., o que significa dizer que os direitos, liberdades e garantias neles acolhidos não podem ser, por força do princípio da aplicabilidade imediata, transformados, automaticamente, em "direitos subjetivos, concretos e definitivos". ${ }^{4}$

No caso da Constituição brasileira, de 1988, creio ser possível extrair uma outra conseqüência importante da norma do $\S 1^{\circ}$, do seu art. $5^{\circ}$, que é a de facultar aos beneficiários de direitos fundamentais estabelecidos por normas de natureza preceptiva e de eficácia limitada a impetração de mandado de injunção, de modo a obter do Poder Judiciário, excepcional, subsidiária e precariamente, com efeitos limitados ao caso concreto, a regulamentação indispensável ao pleno exercício do direito. ${ }^{45}$ É de se observar, contudo, que a jurisprudência do Supremo Tribunal Federal emprestou ao instituto do mandado de injunção efeitos que o aproximaram, demasiada e indevidamente, da ação

${ }^{41}$ Conforme aduz CANOTILHO, J. J. Gomes. Direito constitucional e teoria da constituição. 7. ed. Coimbra: Almedina, 2003. p. 1.224, "este princípio, também designado por princípio da eficiência ou princípio da interpretação efetiva, pode ser formulado da seguinte maneira: a uma norma constitucional deve ser atribuido o sentido que maior eficácia lhe dê".

${ }^{42}$ MIRANDA, Jorge. op. cit.,. t. 4, p. 276.

43 Seria o caso, por exemplo, das garantias contra a utilização abusiva de informações pessoais ou familiares, a serem estabelecidas por lei, nos termos do art. 26, n. 2, da Constituição portuguesa: Id. Ibid., t. 4, p. 277-8. No mesmo sentido, CANOTILHO, J.J. Gomes. Direito constitucional. cit., p. 438.

44 Id. Ibid., p. 438.

${ }^{45}$ De acordo com o art. 5 , LXXI, da Constituição do Brasil em vigor, “conceder-se-á mandado de injunção sempre que a falta de norma regulamentadora torne inviável o exercício de direitos e liberdades constitucionais e das prerrogativas inerentes à nacionalidade, à soberania e à cidadania”. 
direta de inconstitucionalidade por omissão, limitando-se a Corte a declarar a omissão de medida (legislativa ou administrativa) necessária para tornar efetiva norma constitucional e a cientificar o Poder competente para a adoção das providências necessárias, ${ }^{46}$ muito embora haja alguma possibilidade de evolução dessa interpretação pretoriana. ${ }^{47}$ Não se me afigura viável, de toda sorte, que por meio de mandado de injunção se possa obter a fruição imediata de direitos fundamentais aninhados em normas de eficácia limitada de natureza programática, porquanto, nesse caso, a completa operatividade da norma constitucional não depende apenas de sua densificação em nível subalterno (por meio de lei ou regulamento), mas, sobretudo, da implementação de políticas públicas por meio de atividades administrativas de natureza material, custeadas por verbas orçamentárias. ${ }^{48}$

A conclusão inexorável, portanto, é a de que nem todos os direitos sociais consagrados na Constituição do Brasil gozam de completa proteção jurisdicional. Aqueles estruturados em normas de eficácia limitada e natureza programática, como é o caso da expressiva maioria dos direitos sociais prestacionais, em sentido estrito, não consubstanciam, de pronto, direitos subjetivos plena e diretamente exercitáveis perante o Estado-juiz, e isso, a despeito da prescrição do $\S 1^{\circ}$, do art. $5^{\circ}$, da Constituição Federal. ${ }^{49}$

\footnotetext{
${ }^{46}$ Art. 103, $\S 2^{\circ}$, da Constituição brasileira. O acórdão-paradigma da equiparação de efeitos entre mandado de injunção e a ação de inconstitucionalidade por omissão foi proferido pelo STF no MI n. 107-3-DF.

${ }^{47} \mathrm{O}$ primeiro passo já foi dado no julgamento dos Mandados de Injunção n. 283-DF e 232-DF, em que, uma vez escoado o prazo para a regulamentação de normas constitucionais preceptivas de eficácia limitada, passou o STF a lhes atribuir plenitude eficacial, o que foi possível por conterem elas todos os elementos hábeis para que se lhes desse aplicação direta e imediata (tratava-se das normas do $\S 3^{\circ}$, do art. $8^{\circ}$, do Ato das Disposições Constitucionais Transitórias e do $\S 7^{\circ}$, do art. 195, do corpo permanente da Constituição).

${ }^{48}$ Parece apontar no mesmo sentido o pensamento de José Afonso da Silva, ao tentar compatibilizar o disposto no $\S 1^{\circ}$, do art. $5^{\circ}$, da Constituição com a constatação de que inúmeros direitos sociais são definidos por normas de eficácia limitada e aplicabilidade indireta: "Então, em face dessas normas, que valor tem o disposto no $\$ 1^{\circ}$ do art. $5^{\circ}$, que declara todas de aplicação imediata? Em primeiro lugar, significa que elas são aplicáveis até onde possam, até onde as instituições ofereçam condições para seu atendimento. Em segundo lugar, significa que o Poder Judiciário, sendo invocado a propósito de uma situação concreta nelas garantida, não pode deixar de aplicá-las, conferindo ao interessado o direito reclamado, segundo as instituições existentes". Vejase, SILVA, José Afonso da. Aplicabilidade das normas constitucionais. cit., p. 165.

${ }^{49}$ É essa também a conclusão de Andréas KRELL, J. Realização dos direitos fundamentais sociais mediante controle judicial da prestação de serviços públicos básicos (uma visão comparativa). Revista de Informação Legislativa, Brasília, n. 144 p. 243, out./dez. 1999: "Em relação aos direitos sociais, o dispositivo da aplicação imediata não ganha importância maior, visto que esses devem ser tratados de maneira diferente dos direitos clássicos de defesa contra o poder estatal". Anote-se que, no contexto em que foi inserida a frase, pode-se inferir que o autor está se referindo aos direitos sociais de índole prestacional.
} 
2.2. Direitos sociais prestacionais originários plenamente exercitáveis

Consagrou-se, doutrinariamente, a distinção entre direitos sociais originários a prestações e direitos sociais derivados a prestações, emanando os primeiros diretamente da normatividade constitucional e padecendo, em geral, de suas limitações no plano da eficácia, enquanto os demais devem ser entendidos como direitos à "participação igual nas prestações estaduais concretizadas por lei, segundo a medida das capacidades existentes". ${ }^{50}$

Ainda que em caráter excepcional, dada a natureza programática, via de regra, das normas veiculadoras de direitos sociais a prestações estatais, podem existir direitos fundamentais dessa espécie sediados em normas constitucionais de eficácia plena.

Encontramos um bom exemplo disso na vigente Constituição do Brasil, ao tratar do direito à educação. No seu art. $6^{\circ}$, a Carta Magna brasileira arrolou o direito à educação como um dos direitos sociais, ao lado dos direitos à saúde, ao trabalho, à moradia, ao lazer, à segurança, à previdência social, à proteção à maternidade e à infância e à assistência aos desempregados. Cuida-se de norma constitucional tipicamente programática e, por conseguinte, de eficácia limitada, na medida em que os direitos nela consagrados dependem para a sua plena subjetivação da organização e funcionamento de serviços públicos específicos, o que exige disciplina normativa de nível infraconstitucional, mas, sobretudo, a destinação de recursos orçamentários e a estruturação material da atividade estatal. No caso do direito à educação, a norma do art. $6^{\circ}$ é completada pela do art. 205, que estabelece que "a educação, direito de todos e dever do Estado e da família, será promovida e incentivada com a colaboração da sociedade, visando ao pleno desenvolvimento da pessoa, seu preparo para o exercício da cidadania e sua qualificação para o trabalho". Se o Constituinte não houvesse avançado além desse ponto, restaria indiscutível a natureza programática do direito à educação, enquanto típico direito social a prestação estatal, podendo comportar inúmeras facetas, a serem moldadas pelo legislador ordinário, na medida em que as condições econômicas permitissem o efetivo e pleno funcionamento do serviço público correspondente. No que concerne a uma dessas conformações do direito à educação, entretanto, decidiu o Constituinte investir os destinatários de direito subjetivo

\footnotetext{
${ }^{50}$ CANOTILHO, J. J. Gomes. Direito constitucional e teoria da constituição. 7. ed. Coimbra: Almedina, 2003. p. 479, apontando uma importante decorrência dos direitos derivados a prestações: "Os direitos derivados a prestações, naquilo em que constituem a densificação de direitos fundamentais, passam a desempenhar uma função de 'guarda de flanco' (J. P. Müller) desses direitos garantindo o grau de concretização já obtido. Conseqüentemente, eles radicam-se subjetivamente não podendo os poderes públicos eliminar, sem compensação ou alternativa, o núcleo essencial já realizado desses direitos. Neste sentido se fala também de cláusulas de proibição de evolução reacionária ou de retrocesso social (...)".
} 
exercitável de pronto, ao declarar que "o acesso ao ensino obrigatório e gratuito é direito público subjetivo" (art. 208, I e $\left.\S 1^{\circ}\right) .^{51}$

Não apenas a assertividade do $\S 1^{\circ}$ do art. 208 milita em favor da conclusão de que se trata de um direito social prestacional, radicado diretamente na Constituição, desde logo configurado como um completo e definitivo direito subjetivo. O Constituinte inseriu, em paralelo, no texto constitucional inúmeras prescrições que têm por finalidade viabilizar a imediata fruição do direito de acesso gratuito ao ensino fundamental obrigatório, prescrições essas que atuam como verdadeiras garantias desse direito: na organização dos sistemas de ensino nos diversos níveis da federação, determinouse aos Municípios, aos Estados e ao Distrito Federal atuação prioritária no ensino fundamental (art. 211, $\S \S 2^{\circ}$ e $3^{\circ}$ ) ${ }^{52}$ os Estados (e o Distrito Federal) e os Municípios estão obrigados a aplicar, anualmente, pelo menos $18 \%$ e $25 \%$, respectivamente, da receita resultante de impostos, compreendida a proveniente de transferências, na manutenção e desenvolvimento do ensino; o art. 60 do Ato das Disposições Constitucionais Transitórias, com a redação que lhe conferiu a Emenda n. 53, de 19-12-2006, procurou equalizar a distribuição de recursos entre o Distrito Federal, os Estados e os seus Municípios, de modo a assegurar a universalização da educação básica, ${ }^{53}$ compelindo os Estados e o Distrito Federal a criarem fundos de natureza contábil intitulados Fundos de Manutenção e Desenvolvimento da Educação Básica e de Valorização dos Profissionais da Educação - Fundeb, aos quais são aportados, inclusive, recursos federais, para distribuição de verbas às entidades regionais e locais, proporcionalmente ao número de alunos das diversas etapas e modalidades de educação básica presencial, matriculados nas respectivas redes (art. 60, I, II e V, do ADCT); previu-se a responsabilização das autoridades competentes pelo nãooferecimento do ensino obrigatório pelo Poder Público ou sua oferta irregular (art. 208, § $2^{\circ}$ ); facultou-se a destinação de recursos públicos para o custeio de bolsas de estudo para o ensino fundamental (e médio), na forma da lei, para os que demonstrarem insuficiência de recursos, quando houver falta de vagas e cursos regulares da rede pública na localidade

\footnotetext{
51 Nos termos do artigo 32, caput, da Lei Federal n. 9.394, de 20-12-1996 (Lei de Diretrizes e Bases da Educação Nacional), com a redação que lhe conferiu o art. $3^{\circ}$ da Lei n. 11.274, de 6-2-2006, o ensino fundamental obrigatório tem a duração de 9 (nove) anos, iniciando-se aos 6 (seis) anos de idade, e seu objetivo é a formação básica do cidadão.

52 Os Municípios também devem priorizar a educação infantil (art. 211, $\S 2^{\circ}$ ) e os Estados e o Distrito Federal o ensino médio (art. 211, § $3^{\circ}$ ).

${ }^{53}$ Em consonância com a legislação brasileira, a educação básica é mais abrangente do que o ensino fundamental, compreendendo modalidades de ensino de freqüência não-obrigatória, como, por exemplo, a educação infantil e o ensino médio (art. 10, caput, da Medida Provisória n. 339, de 28-12-2006).
} 
da residência do educando, ficando o Poder Público obrigado a investir prioritariamente na expansão de sua rede na localidade (art. $213, \S 1^{\circ}$ ).

O que se constata é o que o Constituinte entendeu ser possível, à luz da realidade sócio-econômica do País, assegurar de imediato o acesso ao ensino fundamental obrigatório a todos os brasileiros, razão pela qual essa projeção do direito à educação foi conformada, em nível constitucional, como um direito exercitável de plano e, nesse sentido, dotado de plena proteção jurisdicional. ${ }^{54} \mathrm{Na}$ hipótese de, concretamente, não existirem vagas suficientes em escolas públicas de ensino fundamental, estão os interessados autorizados a buscar em juízo: a condenação da entidade pública competente (de acordo com a organização coordenada dos respectivos sistemas de ensino e observados os $\S \S$ $2^{\circ}$ e $3^{\circ}$ do art. 211) à obrigação de fazer consistente em proporcionar a matrícula em escola privada de ensino fundamental; a condenação da entidade pública competente no pagamento dos gastos feitos (ou devidos) pela freqüência ao ensino básico obrigatório em escolas privadas; condenação por danos morais em razão do atraso na freqüência ao ensino fundamental. Isso tudo, é claro, sem prejuízo das sanções de natureza administrativa, civil e penal que podem ser impostas às autoridades consideradas responsáveis pelo descumprimento do preceito constitucional.

\subsection{Direitos sociais prestacionais derivados}

Os direitos sociais a prestações delineados por normas constitucionais de índole programática recebem os elementos necessários a seu pleno exercício das normas de nível infraconstitucional, sejam elas legislativas ou regulamentares, ${ }^{55}$ concomitantemente à efetiva implantação do serviço público envolvido no adimplemento da obrigação estatal. Enquanto a eficácia plena dos direitos prestacionais originários emana da própria normatividade constitucional, a dos direitos prestacionais derivados decorre da combinação entre as disposições constitucionais matrizes e as normas infraconstitucionais que as complementam, com início a partir da entrada em vigor dessas últimas.

\footnotetext{
${ }^{54}$ No mesmo sentido, veja-se SARLET, Ingo Wolfang. A eficácia dos direitos fundamentais. 2. ed. Porto Alegre: Livraria do Advogado, 2001. p. 308: "Tudo isso (a disciplina constitucional especifica) demonstra inequivocamente a impertinência, no que diz com um direito subjetivo ao ensino fundamental público gratuito, também dos argumentos relativos à reserva do possivel e da incompetência dos tribunais para decidir sobre a matéria. As regras sobre as competências na esfera do ensino, a origem e destinação das verbas, bem como as prioridades e metas da política do ensino, já estão inequivocamente contidas na própria Constituição".

${ }^{55} \mathrm{Na}$ hipótese de regulação pela autoridade administrativa, não há que se cogitar de ofensa ao princípio da legalidade, pois o direito foi criado, ainda que de modo incompleto, pelo Legislador Constituinte.
} 
Uma vez totalmente configurado o direito social prestacional pela normatividade derivada, não há nenhum obstáculo jurídico para que os sujeitos beneficiários obtenham tutela jurisdicional no caso de algum embaraço à sua fruição. As questões que os direitos prestacionais derivados costumam suscitar são, na verdade, aquelas atinentes ao princípio da isonomia, porquanto não se admitem exclusões arbitrárias de determinadas categorias ou grupos de pessoas do espectro de contemplados, franqueandose aos prejudicados buscar em juízo os benefícios que lhes foram negados, explícita ou implicitamente..$^{56 / 57}$

No Brasil, parte da doutrina, irrefletidamente, tem proclamado que o direito à saúde, no aspecto concernente ao fornecimento de medicamentos pelas entidades públicas integrantes do Sistema Único de Saúde - SUS, dada a sua íntima conexão com o direito à vida, apresenta-se como um direito prestacional originário de eficácia plena, ${ }^{58}$ e assim reconhecido pela jurisprudência majoritária, inclusive do Supremo Tribunal Federal. ${ }^{59}$ Todavia, o exame das disposições da Constituição, de 1988, concernentes ao direito à saúde aponta para a configuração pelo Constituinte de um direito social prestacional sediado em um plexo de normas de eficácia limitada, como é o caso dos art. $6^{\circ}, 196$ e

${ }^{56}$ Desponta, nesse passo, a complexa temática da omissão parcial relativa, cujo suprimento pela via judicial envolve a ponderação de alguns fatores: de um lado, as normas constitucionais programáticas admitem a implementação progressiva, o que se ajusta ao chamado princípio da reserva do possível, tão caro à jurisprudência da Corte Constitucional alemã; de outro, o princípio geral da isonomia não se compadece com tratamento discriminatório sem base constitucional, cabendo ao Poder Judiciário, em face das características de cada sistema jurídico, contornar o problema. No Brasil, que adota um sistema difuso-incidental de controle de constitucionalidade, no qual se comina ao ato inconstitucional a sanção de nulidade, abremse duas possibilidades ao julgador: declarar totalmente inconstitucional a concessão restrita do benefício; ou estendê-lo aos que foram ilegitimamente dele excluídos, mediante a declaração de nulidade da variante interpretativa restritiva (declaração de inconstitucionalidade sem redução de texto, consagrada expressamente no ordenamento brasileiro - art. 28, par. único, da Lei Federal n. 9.868/99).

${ }^{57}$ Sobre o tema, consulte-se op. cit., p. 278-83.

${ }^{58}$ Nesse sentido, o posicionamento de SARLET, Ingo Wolfang. op. cit., p. 302-3: "Por mais que os poderes públicos, como destinatários precípuos de um direito à saúde, venham a opor - além da clássica alegação de que o direito à saúde (a exemplo dos direitos sociais prestacionais em geral) foi positivado como norma de eficácia limitada - os habituais argumentos da ausência de recursos e da incompetência dos órgãos judiciários para decidirem sobre a alocação e destinação de recursos públicos, não nos parece que esta solução possa prevalecer, ainda mais nas hipóteses em que está em jogo a preservação do bem maior da vida humana. (...) O que se pretende realçar, por ora, é que, principalmente no caso do direito à saúde, o reconhecimento de um direito originário a prestações, no sentido de um direito subjetivo individual a prestações materiais (ainda que limitadamente ao estritamente necessário para a proteção da vida humana), diretamente deduzido da Constituição, constitui exigência inarredável de qualquer Estado (social ou não) que inclua nos seus valores essenciais a humanidade e a justiça". Em abono desse ponto-de-vista, manifestaramse, dentre outros, BARROS, Cilaine de Oliveira Guilherme; CARNEIRO, Ruy de Jesus Marçal. Direito à saúde e transformação social. Derecho y Cambio Social, Lima, v. 8 p. 6-9, 2006.

${ }^{59}$ Dentre inúmeros outros, mencione-se o recente acórdão proferido pela $2^{\mathrm{a}}$ Turma do STF, por ocasião do julgamento do Agravo Regimental no Recurso Extraordinário n. 393.175/RS, da relatoria do Ministro Celso de Mello, publicado no Diário da Justiça de 2-2-2007. 
197. O caráter programático dessas normas fica evidenciado quer pela redação inequívoca desses dois últimos dispositivos, que aludem à implementação de políticas públicas e à regulamentação legislativa ${ }^{60}$ quer pelo delineamento, em nível constitucional, de uma rede regionalizada e hierarquizada de ações e serviços públicos de saúde, intitulada de Sistema Único de Saúde - SUS, responsável pela concretização das prestações estatais nessa matéria e cuja efetiva estruturação fícou a cargo do legislador infraconstitucional. ${ }^{61}$ De outra parte, ao contrário do que sucedeu com o direito à educação, que teve um de seus desdobramentos (direito de acesso ao ensino fundamental gratuito) erigido em direito social originário, ou seja, dotado de plenitude eficacial, o direito à saúde, em todas as suas variantes, foi situado constitucionalmente como um direito dependente de legislação e de providências administrativas que completem a sua conformação.

Sucede, porém, que, em relação ao fornecimento de medicamentos pelo SUS, existem normas legislativas e administrativas que o disciplinam, bem como um serviço público de dispensação minimamente organizado, de modo a permitir a caracterização dessa faceta do direito à saúde como um direito social prestacional derivado, plenamente tutelável na esfera jurisdicional. Nesse sentido, a própria linha de defesa desenvolvida pelos órgãos da Advocacia Pública tende a se circunscrever na identificação de abusos no exercício do direito à obtenção de medicamentos gratuitos da rede pública. ${ }^{62}$

\subsection{Ação direta de inconstitucionalidade por omissão e mandado de injunção}

Por ocasião da elaboração da Constituição brasileira, de 5 de outubro de 1988, registrou-se a saudável preocupação de se evitar o pernicioso fenômeno que Karl

${ }^{60}$ Por oportuno, transcrevo os dois dispositivos constitucionais: “Art. 196. A saúde é direito de todos e dever do Estado, garantido mediante políticas sociais e econômicas que visem à redução do risco de doença e de outros agravos e ao acesso universal igualitário às ações e serviços para sua promoção, proteção e recuperação." “Art. 197. São de relevância pública as ações e serviços de saúde, cabendo ao Poder Público dispor, nos termos da lei, sobre sua regulamentação, fiscalização e controle, devendo sua execução ser feita diretamente ou através de terceiros e, também, por pessoa física ou jurídica de direito privado".

${ }^{61}$ O SUS foi estruturado pela Lei Federal n. 8.080, de 19-9-1990, complementada pela Lei n. 8.142, de 28-121990 .

62 Nessa ordem de idéias, o atual Secretário da Saúde do Estado de São Paulo, o Médico Sanitarista Luiz Roberto Barradas Barata, defendeu, em artigo veiculado pela imprensa, a regulamentação legislativa da assistência farmacêutica gratuita, de modo a coarctar abusos que têm sido constatados, especialmente no tocante aos medicamentos de dispensação excepcional, ou seja, "aqueles mais caros, para doenças específicas e de tratamento prolongado, como Aids, esclerose múltipla, hepatite, doença renal crônica”, que acarretam para a Secretaria Estadual da Saúde um dispêndio de cerca de 300 milhões de reais por ano no cumprimento de decisões judiciais que determinam a "distribuição de remédios não-padronizados de eficácia e necessidade duvidosas": Tendências / Debates (É positivo que o Estado seja obrigado por decisão judicial a fornecer certos medicamentos?), Não, regulamentar é o melhor caminho, in Folha de São Paulo, São Paulo, edição de 17-32007 , p. A3. 
Loewenstein denominou de nominalismo constitucional. ${ }^{63}$ Contudo, ao invés de se canalizar esforços para dotar o sistema político de maior racionalidade e eficácia, aprimorandose a representação política ${ }^{64}$ e o sistema de governo, apostou-se na aproximação do discurso constitucional da realidade fática por meio de instrumentos de índole processual, manejáveis perante o Poder Judiciário.

$\mathrm{O}$ que se seguiu foi um desencanto com as soluções engendradas pelo Constituinte, das quais se esperou mais do que poderiam dar, ignorando-se as judiciosas advertências de Konrad Hesse acerca dos limites da força normativa da Constituição e suas instituições. ${ }^{65}$

No plano da tutela de direitos sociais a prestações, as novidades trazidas pela Carta Magna, de 1988, não lograram produzir os frutos que boa parte da doutrina vaticinava no momento de sua entrada em vigor. Não se trata aqui, à evidência, da observância de direitos prestacionais de eficácia plena, quer porque a Constituição os dotou, desde logo, de todas as condições indispensáveis a seu imediato desfrute (direitos originários), quer porque as condições normativas e não-normativas de que careciam de início se perfizeram posteriormente (direitos derivados). A questão se prende à implementação, na via judiciária, de direitos prestacionais veiculados por normas programáticas, acerca dos quais tanto a ação direta de inconstitucionalidade por omissão (art. 103, $\S 2^{\circ}$ ), quanto o mandado de injunção (art. $5^{\circ}$, LXXI), revelaram-se de serventia bastante restrita.

Não é o caso, dados os limites do presente estudo, de se proceder a uma ampla análise desses institutos. A ação direta de inconstitucionalidade por omissão, inspirada no instituto congênere do Direito português (art. 283 da Constituição, de 1976), tipifica instrumento do controle abstrato de normas (controle principal), cabe diante da omissão dos Poderes Públicos na adoção de medida para tornar efetiva norma constitucional. Dada a abrangência de seu objeto, que abarca toda e qualquer omissão na concretização de normas constitucionais de eficácia limitada, é certo que pode ser intentada com fundamento na inércia ou insuficiência da ação do Poder Público relativamente ao gozo de direitos sociais de natureza programática, malgrado se reconheça uma grande dificuldade

${ }^{63}$ LOEWENSTEIN, Karl. Teoría de la Constitución. 2. ed. esp. Tradução de Alfredo Gallego Anabitarte. Barcelona: Ariel, 1976. p. 218.

${ }^{64}$ O Constituinte de 88 teve o mérito de acolher a concepção participativa da democracia, ao estabelecer que "a soberania popular será exercida pelo sufrágio universal e pelo voto direto e secreto, com valor igual para todos, e, nos termos da lei, mediante plebiscito, referendo e iniciativa popular" (art. 14, caput, I a III), porém não atentou para a natureza intermitente e quiçá episódica do uso desses instrumentos, que completam e corrigem, mas nem de longe substituem a representação política ordinária, a cargo dos partidos políticos.

${ }^{65}$ HESSE, Konrad. A força normativa da Constituição. Tradução de Gilmar Ferreira Mendes. Porto Alegre: Fabris, 1991. p. 26-7. 
para a caracterização dessa modalidade de omissão inconstitucional, dada a expressiva liberdade de conformação que se reconhece ao governo, ${ }^{66}$ ao legislador e, em menor grau, ao administrador nessa matéria. ${ }^{67}$ De toda sorte, porém, uma vez julgada procedente a ação, se limita o Supremo Tribunal Federal a dar "ciência ao Poder competente para a adoção das providências necessárias e, em se tratando de órgão administrativo, para fazê-lo em trinta dias". De outra parte, o mandado de injunção, instituto que não encontra paradigma claramente identificável no Direito Comparado, ${ }^{68}$ acabou sendo equiparado, na prática, à ação direta de inconstitucionalidade por omissão pela jurisprudência do Supremo Tribunal Federal, à exceção da legitimação para agir, conferida a qualquer interessado que demonstre a condição de beneficiário do ato legislativo ou administrativo a ser editado. ${ }^{69}$ Assim sendo, em regra, a decisão concessiva da injunção limita-se a reconhecer a omissão inconstitucional e a cientificar o Poder incumbido de colmatá-la, ressalvadas algumas situações específicas de direitos veiculados por certas normas constitucionais preceptivas de eficácia limitada, em que, a despeito da presença de todos os elementos necessários à sua aplicação imediata, o Constituinte subordina-lhe a execução à edição de ato legislativo superveniente (normas condicionadas). No plano dos direitos sociais de natureza programática, como são, de modo geral, os direitos a prestações estatais, resta patenteada a inoperância do mandado de injunção na própria norma constitucional que o abriga, ao estipular que será concedida a injunção "sempre que a falta de norma regulamentadora torne inviável o exercício dos direitos e liberdades constitucionais e das prerrogativas inerentes à nacionalidade, à soberania e à cidadania". ${ }^{70}$ Conforme já se assinalou no item II.1, no que tange aos direitos prestacionais, o maior obstáculo ao seu pleno desfrute não está na ausência de norma regulamentadora e sim na insuficiência de recursos materiais por parte do Estado, inviabilizando a adoção de políticas públicas que satisfaçam inteiramente e, de imediato, ao comando constitucional.

\footnotetext{
${ }^{66}$ Refiro-me, nessa passagem, ao detentor da função de governo, que envolve a escolha e planejamento das políticas públicas.

${ }^{67}$ Jorge Miranda aponta para a sensível diferença de vinculação a que está sujeito o legislador ordinário quando se defronta com normas de eficácia limitada preceptivas ou programáticas, assinalando que, no tocante às primeiras (preceptivas), "embora, ao concretizar, goze de uma relativa liberdade de conformação, esta é bem menor do que relativamente a normas programáticas e, sobretudo, não compreende o poder de apreciação do tempo e das circunstâncias da legiferação": MIRANDA, Jorge. op. cit., t. 4, p. 278

68 Nesse sentido é o magistério de PFEIFFER, Roberto Augusto Castellanos. Mandado de injunção. São Paulo: Atlas, 1999. p. 31-7.

$69 \mathrm{O}$ delineamento complementar do mandado de injunção, à falta de legislação infraconstitucional que o discipline, foi feito pelo próprio STF no julgamento do MI n. 107-3-DF (DJU 21-9-1990).

${ }^{70}$ Constituição do Brasil, art. 5, LXXI.
} 
2.5. O risco de exacerbação do ativismo judiciário

Em Países como o Brasil, detentores de um Produto Interno Bruto considerável, ${ }^{71}$ porém ainda relativamente pobres, sob o ângulo da renda per capita, ${ }^{72}$ e profundamente desiguais, no que toca à distribuição de renda, as expectativas da sociedade em relação à melhoria das condições materiais de vida tendem a se intensificar em velocidade que não consegue ser acompanhada pelo ritmo de implantação e ampliação dos serviços públicos hábeis à sua concretização. No plano jurídico, essa frustração freqüentemente é captada pelos doutrinadores e operadores do Direito, transformandose em propostas de ativismo judiciário, as quais, se implementadas, tendem a provocar a desorganização das finanças públicas, tornando ainda mais precária, em decorrência, a prestação dos serviços estatais. E, pior ainda, o resultado de decisões judiciais que, em vão, tentam suprir, mediante tutelas individuais ou coletivas, a ausência de riqueza suficiente para propiciar o cabal atendimento às necessidades da população, é o aumento da frustração e, inclusive, da desigualdade social, pois não-raramente segmentos melhor organizados e com mais recursos conseguem fazer valer direitos em detrimento da maioria. ${ }^{73}$

Não resta dúvida de que esse ativismo judiciário, ainda contido, mas que vem se disseminando de forma preocupante, ${ }^{74}$ está relacionado a pelo menos dois fatores: de um lado, as disfunções do sistema político, que não tem sido competente para lidar com as reivindicações legítimas que se apresentam, canalizando-as para consistentes planos de governo que, elaborados de forma transparente e participativa, possam atendê-

${ }^{71}$ Em relação ao PIB nominal, o Brasil ficou situado em $12^{\circ}$ lugar no ranking mundial do ano de 2004, segundo dados da página www.estadao.com.br, do dia 31-3-2005.

${ }^{72}$ No tocante ao PIB per capita o Brasil ocupa apenas o $76^{\circ}$ lugar no ranking mundial do ano de 2004 , como informa a página www.estadao.com.br, do dia 31-3-2005.

${ }^{73}$ É o que se observa no Brasil em relação ao fornecimento de medicamentos por ordem judicial, em que decisões por vezes contestáveis até mesmo sob o prisma da saúde pública (inobservância de protocolos médicos do Ministério da Saúde ou de restrições da Agência Nacional de Vigilância Sanitária - Anvisa) vêm provocando autêntica sangria nos recursos do Sistema Único de Saúde - SUS, responsável pelo atendimento à imensa maioria da população, que não tem acesso à medicina privada.

${ }^{74}$ A tal ponto que o próprio Supremo Tribunal Federal extraiu da norma do $\S 2^{\circ}$, do art. 211, da Constituição, segundo a qual "os Municípios atuarão prioritariamente no ensino fundamental e na educação infantil" (de natureza programática em relação à educação infantil, por não estar esta compreendida no ensino fundamental obrigatório), uma obrigação imediatamente exeqüível na esfera jurisdicional, declarando-se: "Embora resida, primariamente, nos Poderes Legislativo e Executivo, a prerrogativa de formular e executar políticas púbicas, revela-se possível, no entanto, ao Poder Judiciário, determinar, ainda que em bases excepcionais, especialmente nas hipóteses de políticas públicas definidas pela própria Constituição, sejam estas implementadas pelos órgãos estatais inadimplentes, cuja omissão - por importar em descumprimento dos encargos político-jurídicos que sobre eles incidem em caráter mandatório - mostra-se apta a comprometer a eficácia e a integridade de direitos sociais e culturais impregnados de estatura constitucional". Acórdão unânime, da $2^{\mathrm{a}}$ Turma do STF, no Agravo Regimental no Agravo de Instrumento n. 410.715-5/SP, da lavra do Ministro Celso de Mello. 
las na medida em que o crescimento econômico o permitir; de outra parte, a cultura nacional, permeada de elevada dose de um voluntarismo inconseqüente e formalista, que simplifica o complexo quadro de um País em busca do desenvolvimento e, por conta dessa simplificação e da formação majoritária de suas lideranças, procura no instrumental jurídico as soluções para todas as deficiências da sociedade.

Não há nada que melhor exemplifique essa tendência do que o debate que se instalou após o advento da Constituição, de 1988, acerca da implementação dos direitos sociais de índole programática. Com base em premissas verdadeiras, como é o caso do princípio da supremacia da Constituição, da vinculação dos Poderes Públicos às normas constitucionais de qualquer natureza, da fundamentalidade dos direitos sociais, da legitimidade do Poder Judiciário para controlar os atos e omissões dos Poderes Públicos etc., são extraídas conclusões altamente contestáveis, de modo a instar os órgãos jurisdicionais, em toda e qualquer circunstância, a tutelar diretamente os direitos sociais a prestações reconhecidos pela Constituição, convertendo os direitos in fieri que, via de regra, o Constituinte proclamou em completos direitos públicos subjetivos. ${ }^{75}$ Não tenho o menor receio de impugnar o caráter "democrático" dessas propostas doutrinárias,

\footnotetext{
75 Apenas para ilustrar, arrolo, a seguir, algumas das inúmeras manifestações doutrinárias dessa coloração. KRELL, Andréas J. Realização dos direitos fundamentais sociais mediante contrale judicial da prestação dos serviços públicos básicos (uma visão comparativa). Revita de Infromação Legislativa, Brasília, n. 144, p. 239-260, out.;dez. 1999. p. 253-4, aduz que "um orçamento público, quando não atende aos preceitos da Constituição, pode e deve ser corrigido mediante alteração do orçamento consecutivo, logicamente com a devida cautela", completando que "em casos individuais, pode ocorrer a condenação do Poder Público para a prestação de determinado serviço público básico, ou o pagamento de serviço privado". CLÈVE, Clémerson Merlin. A eficácia dos direitos fundamentais sociais. Revista de Direito Constitucional e Internacional, São Paulo, n. 54, p. 28-39, jan./mar. 2006, a par de defender o caráter vinculante da peça orçamentária e de exortar a doutrina à construção de uma "dogmática constitucional emancipatória", sustenta: "A vinculação dos poderes públicos aos direitos fundamentais (dimensão objetiva) é suficiente para deles exigir a adoção de políticas públicas voltadas para o seu cumprimento (num horizonte de tempo, evidentemente). Tais políticas, como está-se a sustentar, podem ser inclusive exigidas judicialmente. Se não é, em princípio, possivel reclamar, imediatamente, argumentando com a existência definitiva de posição jurídico-subjetiva positiva de vantagem, os direitos prestacionais ainda não regulamentados (moradia, por exemplo), quando não originários, é perfeitamente possivel a propositura de ação judicial exigente de definição de política de prestação por parte do Estado que possa atender, em prazo razoável, a imposição constitucional". Não se afasta dessa linha o pensamento de GOMES, Dinaura Godinho Pimentel. Direitos fundamentais sociais: uma visão crítica da realidade brasileira. Revista de Direito Constitucional e Internacional, São Paulo, n. 53, p. 53, out./dez. 2005, ao proclamar: "Ao Judiciário compete fazer valer a Constituição Federal, mormente no que concerne à concretização dos direitos fundamentais sociais. Compete, pois, a esse guardião da Lei Maior, fora dos juizos de conveniência e oportunidade, mediante ordens concretas, controlar, sim, as opções do Legislativo e do Executivo, para inibir a mascarada violação dos preceitos constitucionais e possibilitar a transformação da realidade social". Outro adepto dessa corrente, STRECK, Lenio Luiz. A inefetividade dos direitos sociais e a necessidade da construção de uma teoria da constituição dirigente adequada a países de modernidade tardia. Revista da Academia Brasileira de Direito Constitucional, Curitiba, n. 2, p. 25-64, 2002, defende veemente a persistência do modelo de Constituição dirigente, mesmo depois de abandonado pelo seu principal propugnador (Gomes Canotilho).
} 
que vicejam no Brasil sob a aura do "politicamente correto", porquanto traduzem elas a democracia teleológica, tão a gosto do liberalismo clássico, que não se furtava de propugnar sensíveis restrições à participação política, para que não se desviasse o Poder Público da concepção liberal de Estado. Se o próprio Constituinte condicionou a efetiva fruição dos direitos sociais prestacionais a desdobramentos que estão situados no plano do processo governamental, não se afigura compatível com os postulados democráticos e muito menos com o princípio da supremacia da Constituição, a assunção pelo Poder Judiciário de um papel concretizador que, absolutamente, o Constituinte não lhe atribuiu e para o qual não está minimamente legitimado pela cidadania.

Não é essa a doutrina que tem prevalecido na Europa, ${ }^{76}$ mercê dos vigorosos embates ideológicos que serviram para aclarar os argumentos em cotejo e do desenvolvimento econômico que naquelas plagas se logrou alcançar. No Brasil, contudo, a importação irrefletida de categorias conceituais cunhadas em solo europeu pode vir a representar um notável incentivo à exacerbação do ativismo judiciário.

É o que se constata do manejo que vem sendo feito por alguns Autores brasileiros do conceito de mínimo existencial, construído pela Corte Constitucional alemã para superar a ausência de normas referentes aos direitos fundamentais sociais na Lei Fundamental de Bonn. ${ }^{77}$ Pretende-se que o mínimo existencial, derivado do princípio da dignidade da pessoa humana (art. $1^{\circ}$, III, da Constituição de 1988), autorize o Poder Judiciário a assegurar o direito subjetivo a prestações estatais que, minimamente, assegurem

\footnotetext{
${ }^{76}$ É o que se verifica de texto veiculado no sítio eletrônico do Parlamento Europeu (www.europarl.europa. eu), no dia 8-2-2007, acerca da proteção dos direitos sociais fundamentais, intitulados direitos de crédito "cuja efetivação implica uma prestação do Estado elou uma opção política que compete ao legislador": "Eles concernem ao Estado providência e não ao Estado de direito, na medida em que o Estado conserva uma margem de manobra na sua aplicação, sem estar vinculado pelas exigências que cercam as restrições admitidas aos direitos de liberdade (fim legítimo, proporcionalidade). Os objetivos a perseguir (ex.: proteção da saúde) ou os princípios (ex.: direito de greve, limitação da duração do trabalho, direito a férias remuneradas) são reconhecidos em nivel internacional, protegidos pelas Constituições nacionais e, portanto, em princípio, fora do alcance dos Poderes Públicos, o que determina o seu caráter fundamental. Mas, os modos de sua implementação (grau ou nivel de proteção, natureza da prestação) são submetidos à discrição do legislador, mesmo se a sua base constitucional ou convencional lhe imponha, em princípio, a proibição de revogar ou diminuir os dispositivos sociais garantidos pela lei".

${ }_{77}$ Consoante ensina KRELL, Andreas J. op. cit., p. 247, "a teoria engenhosa que liga a prestação do 'mínimo social' aos direitos fundamentais de liberdade (primeira geração) é fruto da doutrina alemã pós-guerra que tinha de superar a ausência de qualquer direito fundamental social na Lei Fundamental de Bonn, sendo baseada na função de estrita normatividade e jurisdicionalidade do texto constitucional". E prossegue: "Assim, a Corte Constitucional Alemã extraiu o direito a um 'mínimo de existência' do principio da dignidade da pessoa humana (art. 1, I, Lei Fundamental), do direito à vida e à integridade fisica, mediante interpretação sistemática junto ao princípio do Estado Social (art. 20, I)". Na verdade, tal teoria foi aplicada, principalmente, para evitar o retrocesso na prestação de serviços públicos essenciais já implantados, reconhecendo-se, nesse caso, um direito social derivado, tutelável pela jurisdição constitucional.
} 
uma existência digna, ficando ao alvedrio dos órgãos jurisdicionais a delimitação do âmbito de abrangência desse estatuto mínimo de direitos prestacionais, olvidando-se que na Constituição do Brasil em vigor foi contemplado um exaustivo elenco de direitos fundamentais sociais, os quais, se fundados em normas de eficácia limitada, ostentam desde logo uma eficácia indireta, compreensiva da cláusula de proibição do retrocesso. É por isso que se pode dizer que o mínimo existencial, no contexto do Sistema Jurídico brasileiro, está devidamente delimitado pela própria Constituição Federal, não ficando da dependência de construções doutrinárias e jurisprudenciais impregnadas de acentuada dose de subjetivismo. Essas condições materiais mínimas a todos asseguradas repousam, em primeiro lugar, no direito ao salário-mínimo, nacionalmente unificado, e que, segundo a norma programática do art. $7^{\circ}$, inciso IV, da Constituição, deve ser capaz de atender às necessidades vitais básicas do trabalhador e de sua família, o que não tem sido plenamente satisfeito pelo legislador infraconstitucional pelo simples e curial motivo de que o atual estágio de desenvolvimento econômico do País não o comporta. ${ }^{78}$ Em segundo lugar, pela organização de um sistema de previdência social, de caráter contributivo e de filiação obrigatória, ${ }^{79}$ sendo certo que, de acordo com o disposto no $\S 2^{\circ}$, do art. 201, da Constituição Federal, "nenhum benefício que substitua o salário de contribuição ou o rendimento do trabalho do segurado terá valor mensal inferior ao salário-mínimo”, norma essa de eficácia plena e aplicabilidade imediata (uma vez organizado o sistema de previdência). Ainda nos domínios da seguridade social, o Constituinte delineou um sistema de assistência social, ${ }^{80}$ em cujo âmbito se assegurou a percepção “de um salário-mínimo de benefício mensal à pessoa portadora de deficiência e ao idoso que comprovem não possuir meios de prover à própria manutenção ou de tê-la provida por sua família, conforme dispuser a lei" (art. 203, V - norma preceptiva de eficácia limitada). Finalmente, o mínimo existencial é assegurado pelo acesso universal e igualitário ao Sistema Único de Saúde - SUS (art. 196 da Constituição - direito prestacional derivado) e pelo acesso, universal e gratuito, ao ensino fundamental obrigatório (art. 208, I - direito público subjetivo plenamente exercitável).

É razoável supor que a própria estabilidade do processo político democrático no Brasil e o correlato amadurecimento institucional que propicia venham a contribuir

\footnotetext{
78 A Medida Provisória n. 362, de 30-3-2007, fixou o salário-mínimo em R\$ 380,00 (trezentos e oitenta reais), a partir do dia $1^{\circ}$ de abril de 2007.

79 O sistema previdenciário brasileiro de há muito foi organizado, estando os planos de benefício regulados pela Lei Federal n. 8.213, de 24-7-1991.

${ }^{80}$ A Lei Federal n. 8.742, de 7-12-1993, dispõe sobre a organização da Assistência Social.
} 
decisivamente para a contenção do ativismo judiciário em limites aceitáveis, o que, por certo, dependerá, igualmente, da formação das novas gerações de juristas e operadores do Direito.

\section{Conclusão}

Os direitos fundamentais de $2^{\mathrm{a}}$ geração, intitulados de direitos econômicos e sociais, não compõem uma categoria submetida a regime jurídico uniforme, especialmente sob o prisma da eficácia desses direitos. Assim é que há direitos sociais fundados em normas constitucionais de eficácia plena e em normas de eficácia limitada, sendo que, nessa segunda hipótese, por vezes as normas apresentam natureza preceptiva e, mais freqüentemente, natureza programática.

No caso dos direitos sociais de caráter prestacional, em regra, são eles veiculados por normas constitucionais programáticas, por depender a sua completa configuração e, em decorrência, o seu pleno exercício, de provimentos normativos de nível infraconstitucional e, sobretudo, da implementação de políticas públicas que importam na destinação de recursos orçamentários e na estruturação material de serviços estatais, algo que está correlacionado ao estágio de desenvolvimento econômico da sociedade.

No Ordenamento Jurídico brasileiro essas diretrizes, firmemente escoradas em estudos comparatísticos, não se mostram diversas, malgrado o disposto no art. $5^{\circ}, \S$ $1^{\circ}$, da Constituição Federal, de 1988, que declara de aplicação imediata todas as normas definidoras de direitos e garantias fundamentais, declaração essa que deve ser recebida cum grano salis, por ser desmentida pelo próprio sistema de direitos e garantias fundamentais positivado pelo Constituinte. Isso não significa, contudo, que na Constituição em vigor no Brasil não se encontre exemplo de direito social prestacional originário de eficácia plena e que não existam inúmeros direitos sociais a prestações estatais de natureza derivada, isto é, direitos que, na atualidade, são amplamente tuteláveis na esfera jurisdicional por força do advento da interpositio legislatoris.

Cumpre afastar o grave risco institucional representado pela exacerbação do ativismo judiciário, canalizando a vontade de Constituição, "maior garantia de sua força normativa", nas palavras de Konrad Hesse ${ }^{81}$, para construções doutrinárias que, preservando a vinculação dos Poderes Públicos às normas constitucionais programáticas,

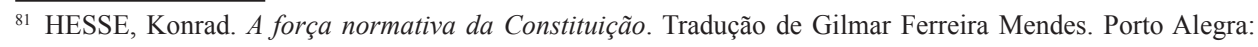
Fabris, 1991. p. 27. 
não atropelem o desenrolar do processo político democrático, principal responsável pelo ajuste entre o projeto constitucional e a realidade sócio-econômica subjacente.

São Paulo, dezembro de 2007.

\section{Referências}

ALCALÁ, Humberto Nogueira. A dignidade da pessoa e os direitos econômicos, sociais e culturais: uma aproximação latino-americana. Revista de Direito Constitucional e Internacional, São Paulo, n. 52, p. 17-43, jul./set. 2005.

ARAÚJO, Luiz Alberto David; NUNES JÚNIOR, Vidal Serrano. Curso de direito constitucional. 10. ed. São Paulo: Saraiva, 2006.

BARCELLOS, Ana Paula de. Neoconstitucionalismo, direitos fundamentais e controle das políticas públicas. Revista de Direito Administrativo, Rio de Janeiro, n. 240, p. 83-103, abr./jun. 2005.

BARROS, Cilaine de Oliveira Guilherme; CARNEIRO, Ruy de Jesus Marçal. Direito à saúde e transformação social. Derecho y Cambio Social, Lima, n. 8, p. 1-11, 2006.

BONAVIDES, Paulo. Curso de direito constitucional. 17. ed. São Paulo: Malheiros, 2005.

BULOS, Uadi Lammêgo. Constituição Federal anotada. 4. ed. São Paulo: Saraiva, 2002.

CANOTILHO, J. J. Gomes. Direito constitucional e teoria da constituição. 7. ed. Coimbra: Almedina, 2003.

. Rever ou romper com a Constituição dirigente? Defesa de um constitucionalismo moralmente reflexivo. Cadernos de Direito Constitucional e Ciência Política, São Paulo, n. 15, p. 7-17, abr./jun. 1996.

CLÈVE, Clémerson Merlin. A eficácia dos direitos fundamentais sociais. Revista de Direito Constitucional e Internacional, São Paulo, n. 54, p. 29-39, jan./mar. 2006.

CORREIA, Marcus Orione Gonçalves. Os direitos sociais enquanto direitos fundamentais. Revista da Faculdade de Direito da Universidade de São Paulo, São Paulo, v. 99, p. 305-25, jan./dez. 2004. FERREIRA FILHO, Manoel Gonçalves. Direitos humanos fundamentais. 7. ed. São Paulo: Saraiva, 2005. 
GARCIA, Emerson. Princípio da separação dos Poderes: os órgãos jurisdicionais e a concreção dos direitos sociais. Revista Brasileira de Direito Constitucional, São Paulo, v. 5, p. 112-36, jan./jun. 2005.

GARRIDO, Diego López et al. Nuevo derecho constitucional comparado. Valência: Tirant lo Blanch, 2000.

GOMES, Dinaura Godinho Pimentel. Direitos fundamentais sociais: uma visão crítica da realidade brasileira. Revista de Direito Constitucional e Internacional, São Paulo, n. 53, p. 40-54, out./dez. 2005.

HESSE, Konrad. A força normativa da Constituição. Tradução de Gilmar Ferreira Mendes. Porto Alegre: Fabris, 1991.

KRELL, Andreas J. Realização dos direitos fundamentais sociais mediante controle judicial da prestação dos serviços públicos básicos (uma visão comparativa). Revista de Informação Legislativa, Brasília, n. 144, p. 239-60, out./dez. 1999.

LOBATO, Anderson Orestes Cavalcante. Os desafios da proteção jurisdicional dos direitos sociais, econômicos e culturais. p. 1-10. Disponível em: <http://dhnet.org.br>.

LOEWENSTEIN, Karl. Teoría de la Constitución. Tradução de Alfredo Gallego Anabitarte. 2. ed. esp. Barcelona: Ariel, 1976.

LOPES, José Reinaldo de Lima. Direitos sociais e justiça. Direito, Estado e Sociedade, Rio de Janeiro, n. 12, p. 117-37, jan./jul. 1998.

MALLET, Estevão. Aplicabilidade das normas constitucionais relativas a direitos sociais. Revista da Faculdade de Direito das Faculdades Metropolitanas Unidas de São Paulo, São Paulo, p. 50-9, 1991.

MIRANDA, Jorge. Manual de direito constitucional. 3. ed. Coimbra: Coimbra Editora, 1996. t. 2. . Manual de direito constitucional. 2. ed. Coimbra: Coimbra Editora, 1993. t. 4.

MORAES, Alexandre. Direito constitucional. 21. ed. São Paulo: Atlas, 2007.

PEGORARO, Lucio et al. Diritto costituzionale e pubblico. Turim: Giappichelli, 2002.

PFEIFFER, Roberto Augusto Castellanos. Mandado de injunção. São Paulo: Atlas, 1999.

ROUSSEAU, Dominique. Droit du contentieux constitutionnel. Paris: Montchrestien, 1990. 
SARAIVA, Paulo Lopo. Garantia constitucional dos direitos sociais no Brasil. 1. ed. Rio de Janeiro: Forense, 1983.

SARLET, Ingo Wolfgang. A eficácia dos direitos fundamentais. 2. ed. Porto Alegre: Livraria do Advogado, 2001.

SARMENTO, Daniel. Direitos sociais e globalização: limites ético-jurídicos ao realinhamento constitucional. Revista de Direito Administrativo, Rio de Janeiro, n. 223, p. 153-68, jan./mar. 2001. SILVA, José Afonso da. Curso de Direito Constitucional Positivo. 27. ed. São Paulo: Malheiros, 2006.

. Aplicabilidade das normas constitucionais. 6. ed. São Paulo, Malheiros, 2003.

- Garantias econômicas, políticas e jurídicas da eficácia dos direitos sociais. Revista da Academia Brasileira de Direito Constitucional, Curitiba, n. 3, p. 301-14, 2003.

STRECK, Lenio Luiz. A inefetividade dos direitos sociais e a necessidade da construção de uma teoria da Constituição dirigente adequada a Países de modernidade tardia. Revista da Academia Brasileira de Direito Constitucional, Curitiba, n. 2, p. 25-64, 2002. 